\title{
O luso, o trópico e o cão tinhoso nas revelações literárias de Honwana ${ }^{1}$
}

Sueli da Silva Saraiva

Universidade da Integração Internacional da Lusofonia Afro-Brasileira (UNILAB), Brasil

Olhou para mim e para o Cão-Tinhoso sem saber com qual de nós os dois havia de correr primeiro. Enquanto pensava para resolver isso cuspiu para nós os dois, isto é, para um sítio entre nós os dois. Está-se mesmo a ver que o cuspo tanto era para mim como para o Cão-Tinhoso. (Honwana, 1980)

\section{Introdução}

O famigerado conceito "lusotropicalismo", formulado na sociologia brasileira por Gilberto Freyre (1900-1987) e cooptado pelo Estado Novo português (19261974) para justificar a manutenção colonial na África, foi peremptoriamente combatido por intelectuais de diferentes espaços e esferas de pensamento. Na década de 1940, as ideias defendidas por Freyre em conferências pela Europa com o assertivo tema "o mundo que o português criou" deram origem a uma compilação publicada sob o mesmo título. Para o autor de "Casa Grande \& Senzala: formação da família brasileira sob o regime de economia patriarcal" (2003), quaisquer espaços constituídos com a presença portuguesa comporiam uma "unidade de sentimento e cultura" ou "um conjunto de valores essenciais de cultura" (Freyre, 1940, p. 32); isto é, uma cultura luso-europeia, humanista e de espírito cristão.

Nesta mesma década, marcada pela perplexidade mundial após 1945, ganha força a contestação internacional, conduzida pelas Nações Unidas, do anacrônico colonialismo português na África. Assim, para "justificar-se" e defender seus últimos domínios imperiais, no início dos anos cinquenta, "o regime sentiu a urgência de reformar a imagem de sua política colonial e respondeu quer através de uma intensa atividade legislativa, quer no plano ideológico" (Cabaço, 2009, p.169). É justamente para atender a este "plano ideológico" que entram em cena, no início da década de cinquenta, Gilberto Freyre e as ideias laudatórias do "jeito

1. Este texto é uma versão revista e ampliada do ensaio: "Desventura e rotina: Luís Bernardo Honwana e o mito do lusotropicalismo na África". In: Rita Chaves; Tania Macêdo. (Org.). Passagens para o Índico: encontros brasileiros com a literatura moçambicana. $1^{\text {ed }}$. Maputo: Marimbique, 2012. 
ameno da colonização portuguesa", pois na sua concepção as perversidades de ordem social e racial cometidas por outras metrópoles europeias, a exemplo da Inglaterra com o abominável regime de segregação na África do Sul, amenizavam e jogavam uma luz humanitária ao regime português.

É de se imaginar que o contexto internacional não estava muito disposto a dar as boas vindas a tal proposta. Num momento em que as Nações Unidas empreendiam uma campanha anticolonialista na África, sugerir a existência de um estilo português não racista de "estar no mundo" não resultava muito convincente. É precisamente nesta época, que o nacionalismo do Estado Novo português reforça seu discurso de cooperação racial na África e, neste caso, as formulações de Gilberto Freyre se apresentam como uma justificativa ideal para a presença colonial portuguesa (Macagno, 2002, p. 102).

\section{Um pacto pelo império}

É preciso observar que, até ao final dos anos de 1940, a tese do sociólogo brasileiro - que ao mesmo tempo em que "resguardava a 'grandeza' de Portugal", também "condenava o racismo e exaltava a miscigenação" (Cabaço, 2009, p. 193) - foram recebidas com desconfiança pelos círculos conservadores próximos ao poder português. Ora, para eles a "afirmação da mística nacional-imperial partia justamente da 'superioridade da raça' cuja 'pureza' a leitura de Freyre punha em questão" (ibid., p. 194). Incomodava, particularmente, a visão freyreana sobre a miscigenação.

Porém, diante da crise colonial em que a república portuguesa se encontrava, governo e intelectualidade do Estado Novo decidem se voltar ideologicamente para as ideias contidas em Casa Grande \& Senzala: formação da família brasileira sob o regime de economia patriarcal, e outras obras freyreanas. Foi assim que, entre 1951 e 1952, Gilberto Freyre empreende o famoso périplo pelas colônias portuguesas na África e Ásia a convite e patrocínio de Lisboa. Neste pacto pelo império, Freyre deveria forjar um "testemunho sociológico", pró-colonialismo, espelhado no modelo brasileiro por ele teorizado, de que também nas chamadas províncias ultramarinas na África e na Ásia imperava uma relação produtiva entre colonos e colonizados; sem relações desiguais em virtude da raça e da cultura. Freyre não decepcionou seus patrocinadores e da viagem surgiram, além de um diário de viagem intitulado "Aventura e rotina: sugestões de uma viagem à procura de constantes portuguesas de caráter e ação" (1953), mais três outros livros,

publicados por encomenda, cujos títulos e subtítulos são autoexplicativos: "Um brasileiro em terras portuguesas: introdução a uma possível luso-tropicologia, acompanhada de conferências e discursos proferidos em Portugal e em terras 
lusitanas e ex-lusitanas da Ásia, África e do Atlântico" (1953); "Integração portuguesa nos trópicos" (1958); "O luso e o trópico - sugestões em torno dos métodos portugueses de integração de povos autóctones e de culturas diferentes da europeia num contexto novo de civilização: o lusotropical" (1961).

Do "contexto novo de civilização" teorizado por Freyre, somente os aspectos que interessavam ao ganho político do império foram apropriados, isto é, "a suposta falta de racismo por parte dos portugueses ou a sua empatia em relação a outros povos ou a fraternidade cristã praticada pelos mesmos dentro e fora de Portugal", conforme recorda Fernando Arenas (2010). Enfim, a bandeira policromada defendida por Freyre continuou, na ideologia portuguesa, a ser um "aspecto que devia ser considerado com rigor".

A ambiguidade inerente a essa "teoria mística sobre a essência do caráter português" (Mondlane, 2011) não passou incólume às críticas dos intelectuais e revolucionários africanos que naquele mesmo período já preparavam o fogo da revolução. Vozes altissonantes se levantaram na tentativa de ou chamar a atenção do sociólogo brasileiro para a verdadeira situação social, política e econômica nos territórios colonizados, ou para criticar frontalmente o caráter falacioso de tais ideias.

\section{Recordando os fatos tropicais}

O ano 1961 foi um divisor de águas na relação entre a metrópole portuguesa e suas então colônias. Os meses de fevereiro e março desse ano foram marcados por uma incisiva onda de "revolta dos colonizados", conforme Carlos Serrano e Kabengele Munanga (1995). Alguns eventos decisivos em Angola marcaram o irreversível processo de autodeterminação dos povos nos últimos territórios ocupados: o ataque aos prédios da Polícia Internacional de Defesa do Estado (PIDE) em Luanda (Cadeia de São Paulo, Casa de Reclusão Militar e Esquadra de Polícia Móvel); o levante da população bakongo (no norte de Angola) contra autoridades portuguesas, fazendeiros de café e seus servidores e a revolta dos trabalhadores do algodão no centro-leste. O encrudecimento dos conflitos, contudo, já se tornara evidente em confrontos anteriores, sempre com desproporcional uso da força direta ou indiretamente autorizada pela metrópole. Exemplo disso foi o massacre de Mueda, ao norte de Moçambique, cuja reivindicação por melhores condições de trabalho e ganho resultara na morte de mais de quinhentos moçambicanos um ano antes. Tais eventos nas então denominadas "províncias ultramarinas", aliados às manifestações antissalazaristas na própria metrópole, obrigavam cada vez mais o governo português a lutar, interna e externamente, para preservar o mito de um império em que Portugal 
e suas colônias formavam "uma nação una e pluricontinental" (Cabaço, 2009, p. 160). Um mito que se fez constar na Constituição de 1951 (exatos dez anos antes de ser aceso o estopim em Angola).

A pressão da comunidade internacional, aliada aos interesses da ONU, EUA e União Soviética, crescia na medida do embate africano contra o regime colonial, e da violenta contrapartida da metrópole. Assim, enquanto Portugal dava início à sua "guerra colonial" em julho de 1961 (com o envio de quase 20.000 soldados para Angola), a Assembleia Geral da ONU criava, em 27 de novembro do mesmo ano, o "Comitê de Descolonização". A história revelaria que tal "descolonização" não ocorreria sem o aporte das armas e a determinação dos africanos anticolonialistas por mais de uma década.

Um dos episódios emblemáticos a contrariar a ideia do lusotropicalismo como sinônimo de integração social e racial foram as divisões institucionalizadas, nos territórios africanos ocupados, entre os que o Estado considerava os portugueses "de fato" (os colonos brancos); os africanos negros nativos, chamados de indígenas; e os africanos negros a quem se outorgava a condição de "assimilado" (ou "civilizados"), desde que, oficialmente, aderissem à cultura europeia em detrimento de sua própria.

Este procedimento de "civilização" forçada, em vigor de 1917 até 1958, não era ignorado por Freyre, que dele fez uma leitura com as mesmas lentes embaçadas que o levaram a vislumbrar o idílico mundo lusotropical. Diz ele, em Um brasileiro em terras portuguesas:

O método [de assimilação], em sua pureza de objetivo e de ação, transformou em Marias e Antonios lusitanamente da Silva ou dos Santos, muita negra e muito negro, de início literalmente da selva, africanamente dos demônios do mato, e a adoção de nomes cristãos e prenomes portugueses importou quase sempre em civilizar-se, aportuguesar-se, cristianizar-se, domesticar-se o selvagenzinho, a ponto de tornar-se [...] filho da casa domesticadora, membro da família educadora (Freyre, 1953, p. 26).

Ganha relevo nesta passagem a visão marcadamente eurocêntrica que permeava o pensamento freyreano. As ações de "civilizar-se, aportuguesar-se, cristianizar-se, domesticar-se o selvagenzinho" para que este se tornasse "filho da casa domesticadora, membro da família educadora" corresponde a subordinar o não europeu, para o seu próprio bem, à casa grande! Uma opinião sobre a questão do assimilado que explicita o quanto os "métodos portugueses de integração de povos autóctones" desconsideravam o reconhecimento dos valores culturais dos povos nativos num plano horizontal. No fim, trata-se de um discurso sociológico contaminado pelas mesmas ambiguidades advindas dos palanques das autoridades portuguesas, conforme Eduardo Mondlane denuncia neste relato: 
Há alguns anos, o então Primeiro-Ministro de Portugal, Dr. António de Oliveira Salazar, declarava: 'Estes contactos (nos territórios ultramarinos) nunca incluíram a mais leve ideia de superioridade ou discriminação racial [...]. Creio poder afirmar que a característica que distingue a África Portuguesa - apesar dos esforços concertados feitos em vários cantos para a atacar tanto por palavras como por acções - é a primazia que sempre demos e continuamos a dar ao reforço do valor e da dignidade do homem sem distinção de cor ou credo, a luz da civilização que levamos às populações que estavam em todos os aspectos distantes de nós' (Mondlane, Apud Sanches, 2011, p. 310).

O discurso freyreano coincide, pois, com a visão estereotipada, mas travestida de humanidade que o Estado português investia nos povos africanos e asiáticos sob o seu domínio. A "casa domesticadora", a "família educadora" de Freyre podem ser interpretadas aqui como metonímia de uma Europa-mãe caridosa, que gerou um bom filho colonizador, incompreensivelmente atacado pelos órgãos internacionais e pela rebeldia de seus protegidos.

\section{Luís Bernardo Honwana, a ficção e as "verdades" lusotropicais}

1961, ano de publicação de O luso e o trópico, terceiro título de Freyre, na lista supracitada, coincidiu, portanto, com o marco inicial das lutas armadas de libertação das últimas colônias portuguesas na África. Em reação aos movimentos independentistas reforçava-se a ebulição dos ingredientes segregacionistas que sempre estiveram na base das sociedades coloniais, conforme atesta o sociólogo moçambicano José Luiz Cabaço, testemunha desta viragem histórica: "Nos primeiros anos da década de 1960, os colonos, aterrorizados com a 'revolta dos negros', acentuaram sua desconfiança e intensificaram a distanciação social” (Cabaço, 2009, p. 171). Se o clima entre os colonos era de terror (fundamentado na história segregacionista e exploratória da ocupação colonial), do lado da revolução que se avolumava, o clima era o do terror institucionalizado via polícia do Estado (PIDE).

Foi nesta época de intensa atividade política e intelectual que surgiu na cena literária de Moçambique o jovem Luís Bernardo Honwana, nascido em 1942. Militante da Frente de Libertação de Moçambique (FRELIMO), Honwana, a exemplo daqueles que davam os primeiros passos na constituição da literatura moçambicana, empresta o saber literário à causa revolucionária, e imortaliza no "macrossistema da literatura de língua portuguesa" (Abdala JR., 2003) um inesquecível cão tinhoso. Sua obra prima e única, publicada em 1964, sob o título de Nós matámos o cão-tinhoso, é um conjunto de narrativas, quase crônicas, da vida cotidiana de Moçambique naquelas décadas pós-Segunda Guerra Mundial. Os 
textos não deixam dúvidas de que o momento histórico em que foram escritos era de resistência e arranque para a luta armada. As denúncias contidas em cada uma das sete narrativas colocam às claras o "maniqueísmo do mundo colonial" (Fanon, 2010), e a sua insustentabilidade por parte do decadente império, a despeito da campanha lusotropicalista encetada na década anterior.

Em seu texto "Resistência - a procura de um movimento nacional", já referido, o líder revolucionário Eduardo Mondlane analisa os acontecimentos político-sociais de Moçambique nas primeiras décadas do século XX até ao início da luta armada nos anos sessenta, e menciona o protagonismo da narrativa do jovem Honwana neste processo de resistência intelectual, tanto pela descrição dos comportamentos humanos quanto pela denúncia das condições de vida sob um governo opressor:

Os contos de Luís Bernardo Honwana, que tem sido amplamente reconhecido fora de África como um mestre nesta arte, levam o leitor a fazer as mesmas denúncias através de uma análise perceptiva e detalhada do comportamento humano. Seguindo uma longa tradição de artistas que vivem debaixo de um governo repressivo, este escritor escreve por vezes em forma de parábolas, ou centra a sua história à volta de um acontecimento concreto aparentemente insignificante, mas que ele utiliza para focar uma situação abrangente (Mondlane, Apud Sanches, 2011, p. 341).

Os enredos reverberam, inclusive, episódios vividos pela própria família Honwana. Ao dialogar literariamente com as questões de sua infância e juventude, o escritor Honwana deixa entrever pelo viés literário os verdadeiros "métodos portugueses de integração de povos autóctones", para nos remetermos ao subtítulo de $O$ luso e o trópico (Freyre) publicado três anos antes do surgimento de $O$ cão-tinhoso.

Ao contrário da condição de liberalidade proferida pelas obras colonialistas de Freyre, os narradores de Honwana, cujo preferido é o menino Ginho (uma espécie de alter ego do autor quando criança), revelam a ausência de qualquer horizontalidade, no sentido de igualdade de direitos, no espaço dominado. Fosse no campo cultural, econômico, jurídico ou social, o que se destacava era um cenário condensado pela desigualdade institucionalizada: a própria essência do colonialismo. O topo da pirâmide social nas colônias portuguesas ganhou novo peso com outra onda de colonos aportados no início dos anos de 1950; uma onda que trouxe de arrasto um estoque reforçado de privilégios a uns e opressão a outros: "os anos 50, que alguém chamou de 'década do silêncio' e que os colonos mais antigos consideraram 'os anos de ouro', foram marcados por uma intervenção incisiva do Estado em benefício do colono" (Cabaço, 2009, p. 221). 
Pelas vozes narrativas dos contos de Honwana, revela-se um quadro social onde o lugar de cada indivíduo e grupo, desde a infância até à velhice, se encontrava previamente definido e sempre em prejuízo dos africanos negros e mestiços. Um panorama sombrio vai se desvelando em jogos de meninice só aparentemente ingênuos ("Nós matámos o cão-tinhoso"); na cidadania remediada das famílias de africanos negros assimilados ("Inventário de imóveis e jacentes"; "Papá, Cobra e eu"); na coisificação da pessoa ("Dina"); na miséria, no racismo e na juventude condenada ("A velhota"); na visão estereotipada e desumanizada do africano negro ("As mãos dos pretos") e na exploração do trabalho e expropriação das terras ("Nhinguitimo"). No entanto, em todas essas narrativas estão latentes o sopro da resistência e o germe da luta armada. Pelas rememorações dos narradores ressurgem lugares, personagens e eventos do cotidiano colonial em um tempo não muito distante daquele em que se narra. Tendo em mente que Hownana, nascido em 1942, viveu sua infância e adolescência nos anos 40-50, alguns fatos remetem à biografia do próprio autor e podem, inclusive, ser confrontados com relatos autobiográficos do livro de memórias de seu pai, Raúl Bernardo Honwana.

\section{Da desventura cotidiana ao desvelamento do mito}

A desmistificação da retórica lusotropical que subjaz nas entrelinhas da obra de Honwana encontra a sua raiz no conceito ético de resistência, no sentido dado por Alfredo Bosi: "resistir é opor a força própria à força alheia" (Bosi, 2002, p. 118). O crítico brasileiro propõe que, no campo literário, a resistência se dá como tema [pelo conteúdo], e também como processo inerente à escrita [pela forma] (ibid., p. 120), e que "a translação [do conceito] da esfera ética para a estética é possível", e ocorre "quando o narrador se põe a explorar uma força catalisadora da vida em sociedade: os seus valores" (ibid.). A exploração dos valores, como conteúdo literário, pressupõe a existência do seu contrário, os antivalores. "Exemplos de valores e antivalores são liberdade e despotismo; igualdade e iniquidade; sinceridade e hipocrisia; coragem e covardia; fidelidade e traição etc.”, conclui (ibid.). É justamente essa exploração de "valores" e crítica aos "antivalores" na sociedade colonial moçambicana que subjaz aos enredos de Nós matámos o cão-tinhoso. Marca de uma resistência que jamais esteve ausente da história dos povos africanos:

A contestação dos filhos da terra era marcada, com firmeza e extrema dignidade, pela defesa de princípios e de valores éticos que a 'missão civilizadora' proclamava, mas que não respeitava nem punha em prática nas relações com os colonizados (Cabaço, 2009, p. 128).

"Resistir", defende Alfredo Bosi, corresponde ao contrário de "de/sistir"; antes, o "cognato próximo é in/sistir" (Bosi, 2002, p.118). O campo social mo- 
çambicano foi marcado sempre pelo signo da resistência e insistência. No caso literário, recordem-se da gradativa resistência aos dogmas da escola canônica e a busca de novas experimentações, a exemplo das propostas estéticas do modernismo brasileiro. Mas, se na literatura moçambicana, a forma foi apropriada por afinidades estéticas eletivas, o conteúdo que preenche tal forma não deixa dúvidas de sua origem: trata-se de um mundo hostil às mudanças nos jogos de poder, e em nada semelhante às teorias freyreanas.

No conto "Inventário de imóveis e jacentes", o narrador Ginho é um menino insone que faz um "inventário" mental de seu ambiente familiar: uma casa só confortável na aparência, pois, apesar da divisão em cômodos com alguns móveis e objetos dispostos a la cultura europeia, ela é pequena para a numerosa família de pai, mãe e oito filhos: "O ar está pesado neste quarto, porque além de estar tudo fechado, dormem aqui, incluindo-me, 5 pessoas. Às vezes somos 6 e isso dá-se mais frequentemente [...]" (Honwana, 1980, p. 36). A descrição dos objetos exemplifica a experiência de uma família de assimilados, que apesar de alojados num modo de vida dito civilizado, jamais recebem iguais condições materiais para usufruir dos mesmos benefícios dos cidadãos portugueses "de verdade", os colonos brancos. Destaca-se no ambiente remediado o cuidado com a educação das crianças (caixotes com livros e material de desenho e pintura sob as camas; a estante com livros na sala; as inúmeras revistas nos quartos e na sala). Também fica evidente a dificuldade de se alcançar o conforto material: um único colchão de sumaúma (o "luxo" da casa), enquanto os demais são de palha; o berço único para ser utilizado simultaneamente por dois bebês; a velha mesa de jantar com sete cadeiras ("uma de cada espécie"); as cortinas de tecido "grosso e amarelado"; a máquina de costura e o rádio e as revistas desatualizadas espalhadas pela casa; essas últimas um exemplo emblemático do cumprimento do dever do assimilado/civilizado. Mas, o aparente esforço para apreender a cultura do outro, o colonizador, apresenta um lado de contestação:

Se agora quisesse ler uma revista ia direitinho à mesa do centro, porque lá é que estão as "Lifes", as "Times" e as "Cruzeiros" mais recentes. Nos outros lugares da sala de visitas estão as revistas mais antigas e as mais ordinárias. Na mesa do centro está também o "Reader's", mas talvez nem lhe tocasse porque parece que não é grande coisa. O Papá diz que é uma porcaria. Bem, mas para ele todas as revistas que Mamã costuma pôr na sala de visitas são uma porcaria. É por isso que não tenho assim tanta vontade de sair da cama, embora não tenha sono nenhum (Honwana, 1980, p. 39).

Essa passagem que encerra o conto ilustra a crítica, consciente ou não, de parte dos assimilados em relação à imposição cultural a qual eram submetidos. 
A resistência a esses antivalores é verbalizada na narrativa pela depreciação das publicações (“O Papá diz que é uma porcaria”) e pela atitude do narrador, apenas supostamente passiva, mas de resistência manifesta pela recusa da exploração da casa "decorada" com a cultura imposta ("É por isso que não tenho assim tanta vontade de sair da cama, embora não tenha sono nenhum").

A história revelaria que mesmo os assimilados que aceitaram tal condição - alguns mais por necessidade do que por opção - não se congratulavam plenamente com o estatuto. Em seu livro de memórias, Raúl Bernardo Honwana, pai de Luís Bernardo, reflete sobre o processo de assimilação:

Nem todos os africanos aceitaram esta lei que consistia no seguinte: o africano que se considerasse 'civilizado' devia fazer um exame, respondendo a certas perguntas e deixando que uma comissão fosse à sua casa ver como é que vivia, se sabia comer como um branco, à mesa, se se calçava e se tinha uma só mulher. Quando ele era aprovado, passavam-lhe um documento chamado o 'alvará de assimilação' pelo que se pagava meia libra-ouro ou o seu correspondente (Honwana, 1989, p. 69-70).

A casa inventariada pelo menino-narrador representa uma situação abrangente, como expressou Mondlane. Tendo sido "aprovada" pelos inquisidores e seus moradores identificados como "civilizados", estabelecia-se a divisão sociocultural entre aqueles que eram do mesmo modo subjugados. Na passagem dedicada ao empregado Madunana, sempre em companhia do cachorro Totó (ambos reaparecerem em "Papá, Cobra e Eu"), o empregado negro e o cachorro dormem, juntos, na cozinha fora da casa, uma "palhota que se construiu a um canto do quintal. [...] quase negra, tanto por dentro como por fora. [...] A palhota não tem nada a vedar a entrada..." (Honwana, 1980, p. 37). Se entre os africanos negros e mestiços se implantava a semente da desigualdade social (para melhor dominar), entre os colonos brancos e os negros assimilados cultivava-se a desigualdade social e racial que jamais arrefeceu. Ou seja, entre a teoria institucional e a prática da cidadania havia uma muralha intransponível para o grupo dos assimilados.

Enquanto a situação dos assimilados era inexoravelmente remediada, a vida dos chamados indígenas (não assimilados) regia-se pelo signo da impossibilidade mediada particularmente pelo racismo. Eduardo Mondlane relata que os colonos portugueses eram muitas vezes mais racistas que o próprio governo em relação aos não brancos, derrubando o mito da teoria do lusotropicalismo:

Em Tete, em 1948, [...] quando pela primeira vez as autoridades permitiram os filhos dos não-brancos frequentar a escola primária, os colonos brancos protestaram vigorosamente; vendo que o seu protesto não dava resultados, insistiram em que deviam ser deixadas duas filas de carteiras vazias para separar os seus filhos dos outros não brancos. (Sanches, 2011, p. 331). 
Considerados apenas como força de trabalho destituída de ser, os africanos negros que não exibissem, sempre que solicitados, o bilhete de identidade de "civilizado", ou que ousassem adentrar os espaços sociais que lhes eram socialmente interditos, eram imediatamente submetidos à "educação" pela força tacitamente assumida por grande parte dos colonos.

Tal situação é exemplificada na história narrada em "A velhota". Neste conto, o narrador é um jovem negro, cujo desespero diante de situações de humilhação e injustiça o levará à inevitável resistência. O adolescente - aparentemente o arrimo de sua família - vive com a mãe (a velhota) e irmãos menores, "chatos e barulhentos", como afirma. Seu lar é um ambiente de muita pobreza. Para escapar a essa situação cotidiana, ele posterga o seu retorno ao lar após o trabalho, permanecendo na "cidade proibida". A narrativa inicia-se quando, numa dessas ocasiões, o narrador é espancado dentro de um bar. A caracterização do agressor não deixa dúvida de que se trata de alguém de classe social prestigiada, não negro, como o enredo revelará. Nocauteado e oprimido pelo corpo do adversário (metaforicamente, o corpo social colonialista), o narrador relata:

[...] vi as duas pernas vestidas de escuro, que, nascidas uma de cada lado do meu corpo, cresciam longamente para cima, tesas e tensas, convergindo para a placa de metal brilhante do cinto. Por cima delas, lá em cima, perto da lâmpada do teto, a cara fitava-me, atenta, sorrindo satisfeita (Honwana, 1980, p. 54).

Rente ao chão, preso pelas pernas do agressor, com a visão do cinto (comumente usado para castigo), o jovem negro não podia revidar fisicamente. Na concepção colonialista, aquele espaço de lazer e convívio social não era o seu lugar. Nestes ambientes, os não brancos, mesmo os negros assimilados ou mestiços não conviviam. Ao narrador-personagem não resta outro caminho senão voltar para o seu lugar, a casa materna que, apesar da miséria, da "velhota insípida e os miúdos chatos e barulhentos" (p. 55) era o seu refúgio:

[...] não era nada que se comparasse àquilo do bar, de há bocado, ou de todos os outros bares, restaurantes, átrios de cinemas ou quaisquer outros lugares no género em que todos me olhavam duma maneira incomodativa, como que a denunciar em mim um elemento estranho, ridículo, exótico e sei lá o que mais (Honwana, 1980, p. 55).

A agressão física e psicológica da "cidade proibida" o empurra sempre de volta para a "casa da miséria", uma casa construída e mantida pelo mesmo sistema de exclusão (muito distante da suposta integração lusotropical), reforçando a sua subalternidade na ordem colonial. Essa miséria humana à qual o relegam será, por exaustão, a sua epifania, o fogo prometeico da resistência, conforme ele já indicava ao deixar o bar onde fora espancado: 
Eu precisava de ir para casa. Ia comer arroz e caril de amendoim como eles queriam que fizesse, mas não para encher a barriga. E precisava de ir para casa para encher os ouvidos de berros, os olhos de miséria e a consciência de arroz com caril de amendoim (Honwana, 1980, p. 55).

Assim, ao chegar em casa, ele solidariza-se com a miserável família em sua luta pela sobrevivência, e encontra alento no abraço materno: "Eles fizeram-me pequenino e conseguem que eu me sinta pequenino" (p. 59). Durante o silencioso abraço, diante da panela vazia, o narrador reconhece o inevitável: "Tenho a impressão de que só neste momento é que vi as chamas, embora estivesse há muito tempo a olhar para elas. O seu calor era bom" (p. 59). Confundem-se, simbolicamente, o calor dos braços da mãe (alegoria da mãe-terra) e o calor das chamas acesas (alegoria da luta). Enfim, uma chama que se propõe a resistir àquele estado de coisas.

Subjacente aos temas que norteiam os textos de Honwana - falácia da assimilação, racismo, intolerância, miséria etc., está a exploração da força de trabalho dos africanos negros e mestiços em suas várias vertentes: salários desiguais pagos aos empregados assimilados; subemprego e contrato forçado dos não assimilados (indígenas); exportação de mão de obra para as degradantes minas da África do Sul, até a prostituição como meio de sobrevivência.

São temas que aparecem no conto "Dina". ${ }^{2}$ Ali, narra-se ao mesmo tempo a labuta dos trabalhadores nas fazendas dos colonos, a exploração, a humilhação e a sabedoria para reconhecer o momento e as condições adequadas para o enfrentamento. $\mathrm{O}$ enredo traz o velho negro Madala, que mesmo entregando-se ao trabalho fatigante numa plantação de milho, não provê o suficiente para a família. Numa ocasião, ele vê sua filha Maria, prostituída, recebendo o "pagamento" do capataz branco da fazenda onde - "dobrado sobre o ventre e com as mãos pendentes para o chão" - Madala trabalhava retirando as ervas-daninhas da plantação. A prostituição da filha, que não era segredo para o velho pai e feria-o profundamente, foi escancarada ao sol ardente do meio-dia, aos olhos de todos os trabalhadores da plantação. E, sendo Madala o mais-velho, respeitado e querido, os amigos mais próximos se solidarizavam com o seu desespero paterno. Outros trabalhadores, comandados por um jovem em formação revolucionária, viam na ocasião a oportunidade para iniciar uma rebelião.

Mas, apesar da dor e da revolta, o mais-velho pondera sobre o perigo latente na disposição de seus companheiros. O desejo dos mais jovens de incendiar um levante desarmado no calor da hora daquele meio-dia descambaria na já conhe-

2. "Dina" significa almoço, intervalo do meio-dia, em fanagalô, crioulo das minas da África do Sul, cf. Honwana, 1980 , p. 40, nota 1. 
cida contrapartida, desproporcionalmente sangrenta, por parte das autoridades coloniais (recorde-se o já referido massacre de Mueda, em 1960).

Ao ouvir da humilhada Maria, constrangida pelo fato de Madala e todos os outros a terem visto receber uma moeda do capataz por "serviços prestados", o capataz, temeroso com a reação dos empregados, tenta impor sua autoridade, ordenando a volta dos homens ao trabalho ("Então, rapazes?! Não ouviram?... Já tocou! Acabou o dina! - O capataz gritava com uma irritação crescente”, p. 52). Sem obter resultado pela autoridade do mando e percebendo a tensão crescente entre os trabalhadores, que esperavam uma reação digna de um pai ofendido, o capataz decide compensar o velho oferecendo-lhe uma garrafa de um vinho ordinário. Madala, então, contrariando os olhares dos companheiros, e ciente do ato necessário, aceita e bebe de uma só vez a garrafa:

Madala relanceou o olhar pelas fisionomias ansiosas que o cercavam. A garrafa estava toda suada e o vinho era de um amarelo sujo, avermelhado. Bebeu-o de uma única vez, deixando que uma boa parte lhe molhasse as barbas e lhe escorresse pelo pescoço. Depois devolveu a garrafa vazia ao capataz (Honwana, 1980, p. 53).

Após ser insultado pelo jovem que ansiava pela luta imediata, e ter seu ato compreendido pelos demais companheiros, o velho volta ao trabalho, ciente de que resistir com sabedoria não é sinônimo de desistência, mas de postergação para uma luta em condições compatíveis.

As desventuras dos grupos subjugados no sistema colonial adquirem a dimensão épica no conto que dá título ao livro, "Nós matámos o Cão-Tinhoso". Trata-se de uma história aparentemente despretensiosa do narrador-menino, o negro Ginho, que expressa um sincero mea-culpa sobre como ele foi levado a participar do sacrifício de um cão sarnento (tinhoso) que rondava a sua escola. Ginho, que não se isenta do grupo dos que repudiavam o cão, faz do espaço da narrativa o seu confessionário, um local ao mesmo tempo de expiação e denúncia da situação de terror e impotência diante de um ato de covardia, que vitimou mais do que o cão - metáfora de todo um grupo de seres considerados inferiores e que deviam ser, se possível, eliminados. Desmistifica-se, portanto um mundo hostil àquele considerado repugnante por escancarar a miséria de uma existência oprimida, um mundo de intolerâncias maquiado com as cores opacas da propagada "civilização".

Cada detalhe do narrado, como a personificação do cão que "tinha uns olhos azuis", confirma a metaforização de uma humanidade ao mesmo tempo aviltada e desafiadora; humilhada e resistente: "... Metiam medo aqueles olhos, assim tão grandes, a olhar como uma pessoa a pedir qualquer coisa sem querer dizer" (p. 5). 
A conversa lacrimosa que o narrador enceta deságua no íntimo de seu interlocutor como uma prosa "incomodativa", nas palavras de Lepecki (2004): "Não se percebe bem por quais razões a fala tão simples, o andar tão lento, a quase pachorra no dizer das coisas pode ir se condensando, devagarinho, numa espécie de opressão. O mal-estar instala-se" (p. 45-46). O "mal-estar" de um leitor-confessor que ouve, no silêncio da leitura, a confidência de um pecado mortal, cujo fardo ele passa a compartilhar em obediência a um sacramento involuntário. Ao fim, resta-lhe absorver o narrado e submeter-se à perplexidade. Há uma necessidade premente de exorcizar os demônios da vil humanidade que emanam do quadro narrado. E, tal qual um Hamlet alucinado, clamar ao espectro do cão: "Dize-me: para que tudo isso? A que fim obedece? Que deveríamos fazer?" (Shakespeare, Hamlet, Ato I, cena V).

Afinal, as personagens do enredo eram crianças desviadas de sua infância para um caminho de "antivalores" - intolerância, preconceito e ódio. De um lado, o menino negro Ginho (metonímia do colonizado), de outro, o menino branco Quim (metonímia do colonizador), e entre eles um cão apavorado, recordando a ambos o lugar social que o Estado colonial hes outorgava:

\footnotetext{
O Cão-Tinhoso já não fazia força e de repente senti a corda lassa. Daí a pouco o Cão-Tinhoso encostava-se às minhas pernas, todo a tremer e a chiar baixinho. $\mathrm{O}$ Quim acabou de meter o cartucho num dos canos da espingarda e endireitou-a devagar até fechar a câmara. A arma ficou voltada para mim. Eu não pude olhar mais para lá, mas era por causa dos olhos do Quim, que me olhavam quase fechados, a brilhar sem ele estar a chorar. Eu é que tinha uma danada vontade de chorar mas não podia fazer isso com aqueles todos a olhar para mim (Honwana, 1980, p. 22, grifo nosso).
}

A simbiose cão-menino, ambos acuados pela violência dos olhos de seu opositor e pelos canos da espingarda, ilustra, mais uma vez, a falsidade da teoria lusotropical sobre a "integração portuguesa nos trópicos" (cf. Freyre, 1958). Na lógica colonialista, o lugar do sujeito-menino e o lugar do sujeito-cão equivaliam-se. Como expressou uma personagem, o administrador colonial, ao irritar-se tanto com o cão quanto com Ginho: "Eh! Quem é que disse que isto não era a Arca de Noé?” (Honwana, 1980, p. 12).

\section{Considerações finais}

Gilberto Freyre é considerado um dos baluartes do pensamento social brasileiro, em especial por ser o primeiro a apreciar os africanos negros no Brasil como objeto digno de uma análise sociológica que destacasse a sua efetiva participação na construção da sociedade brasileira. Até então, os africanos e seus descendentes eram vistos no Brasil (contrariando, de saída, a própria ideia de integração do 
lusotropicalismo) meramente como força de trabalho, destituídos de cultura e relegados à invisibilidade social. Portanto, ainda que atravessado por ambiguidades (tal e qual a formação do Brasil), é inegável que o pensamento freyreano fez avançar a pesquisa sociológica na ex-colônia portuguesa na América.

Porém, tal ganho sociológico foi, em muitos aspectos, transcendido pelos estudos que se seguiram, os quais desmistificaram a ideia redentora da miscigenação brasileira (eixo da teoria freyreana) como fruto da boa graça do "mundo que o português criou". Teóricos como a antropóloga brasileira Lílian Moritz Schwarcz, para citar apenas um dos nomes mais recentes, têm demonstrado que, nem as relações interraciais tiveram por base a afinidade e respeito ao elemento africano, tampouco a sobrevivência do negro no Brasil, resistindo a toda ordem de arbitrariedades que lhe são impostas, fizeram desmoronar o muro firmemente construído entre a "casa grande" e a "senzala". Logo, se há consenso sobre o ineditismo da teoria freyreana, igualmente se reconhece que a prática social tem contrariado suas conclusões.

De tal modo, as reflexões de Gilberto Freyre sobre um certo lusotropicalismo na África, feitas cerca de vinte anos após o lançamento de sua obra basilar (Casa grande \& senzala), têm sido igualmente objeto de especulações várias, inclusive pela sua vinculação com o Estado Novo português e sua insistência em manter um anacrônico regime colonial, contrariando um mundo assolado pelos eventos da II Grande Guerra.

A história do colonialismo europeu na África terminou, pelo menos oficialmente, há cerca de quarenta anos - um tempo histórico pouco amadurecido, é fato. De tal modo, uma parte da intelectualidade que se debruça sobre o tema ainda procura compreender o legado e o matiz deste tempo de opressões e resistências, e das mentalidades que nele se formaram. Tais reflexões têm levado em grande conta a doutrina do lusotropicalismo, ora para criticá-la, ora para saudá-la.

Contudo, o interesse pelas ideias freyreanas não se reflete apenas em especulações acadêmicas. Também implica ações práticas em tempos de globalização, pós-colonialismos, culturalismos e multiculturalismos (afinal, para que discutir o racismo num mundo que pode ser explicado pelo lusotropicalismo?). De tal modo, no universo da intelectualidade "pós-colonial", o "lusotropical" ganharia novas roupagens, encostando, não raro, em conceitos como mestiçagem, crioulidade e hibridismo, burlando a crítica ligeira. A influência do lusotropicalismo, como teoriza a pesquisadora Claudia Castelo, "ter-se-á alargado, progressivamente, do campo cultural para o campo político, e deste para o das mentalidades" (1999, p. 14).

Procuramos nestas reflexões descortinar o quanto a resistência intelectual às ideias lusotropicalistas esteve presente, direta ou indiretamente, no discurso dos 
intelectuais africanos empenhados nos movimentos anticoloniais em Moçambique, e também em outros territórios colonizados. Escritores como Luís Bernardo Honwana não se agitavam apenas pela emancipação política de seu país, como foi o caso da independência do Brasil, ou poderia até ser a pretensão de alguns colonos portugueses nos territórios africanos, descontentes com a intervenção da metrópole em "seus" domínios. No bojo das reivindicações pela autodeterminação dos povos africanos e de libertação total das amarras do velho império, que resfolegava na segunda metade do século XX, colocava-se por terra a retórica de "um só povo uma só nação", um mito que buscou lastro na teoria freyreana importada do Brasil. Ao se oporem à calamitosa subjugação social, econômica, cultural e política que organizava a dinâmica da sociedade colonial, favorecendo exclusivamente um pequeno grupo dominante, os agentes da mudança, usando armas concretas e simbólicas, desmascararam o discurso fundado numa fantasia político-ideológica e numa cegueira voluntária, devidamente apropriado pelo Estado Novo português.

$\mathrm{Na}$ sua sempre precisa leitura antropológica sobre o mito freyreano, Lorenzo Macagno recorda que "de fato, o mundo que o português havia criado (ou, melhor, imaginado) podia ser, tanto o paraíso de 'harmonia racial' que alguns visitantes, viajantes e pesquisadores pretendiam encontrar no Brasil”; porém, para olhos e mentes verdadeiramente iluminados, tal mundo seria "o inferno de exploração, segregação e violência" (Macagno, 2002, p.102). O que prevaleceu na história testemunhada pela ficção (?) do imortal "Nós matamos o cão tinhoso" foi a desconstrução de um mito e a demonstração da prevalência do "inferno de exploração, segregação e violência", marcas indeléveis de quaisquer regimes de dominação.

\section{Referências}

Abdala Junior, Benjamin. De voos e ilhas: literatura e comunitarismos. Cotia: Ateliê Editorial, 2003.

Arenas, Fernando. "Reverberações lusotropicais: Gilberto Freyre em África 1 - Cabo Verde". In: Buala - cultura contemporânea africana, 2010. Disponível em: http://www.buala.org/pt/a-ler/ reverberacoes-lusotropicais-gilberto-freyre-em-africa-1-cabo-verde. Acesso em: 20 mar. 2012.

Bosi, Alfredo. Literatura e resistência. São Paulo: Companhia das Letras, 2002.

Cabaço, José Luís. Moçambique: identidade, colonialismo e libertação. São Paulo: Ed. UNESP, 2009.

Castelo, Cláudia. "O modo português de estar no mundo": O luso-tropicalismo e a ideologia portuguesa (1933-1961). Porto: Edições Afrontamento: 1999.

Honwana, Luís Bernardo. Nós matámos o cão-tinhoso. São Paulo: Ática, 1980. 
Honwana, Raúl Bernardo. Memórias. Lisboa: Edições ASA, 1989.

Fanon, Frantz. Os condenados da terra. Juiz de Fora: Editora da UFJF, 2010.

Freyre, Gilberto. Casa Grande \& Senzala: formação da família brasileira sob o regime de economia patriarcal. 48.ed. São Paulo: Global, 2003.

Freyre, Gilberto. O mundo que o português criou. Lisboa: Livros do Brasil, 1940.

Freyre, Gilberto. Aventura e rotina: sugestões de uma viagem à procura de constantes portuguesas de caráter e ação. Rio de Janeiro: José Olympio, 1953.

Freyre, Gilberto. Um brasileiro em terras portuguesas: introdução a uma possível luso-tropicologia, acompanhada de conferências e discursos proferidos em Portugal e em terras lusitanas e ex-lusitanas da Ásia, África e do Atlântico. Rio de Janeiro: José Olympio, 1953.

Freyre, Gilberto. Integração portuguesa nos trópicos. Lisboa: Ministério de Ultramar, 1958.

Freyre, Gilberto. O luso e o trópico. sugestões em torno dos métodos portugueses de integração de povos autóctones e de culturas diferentes da europeia num contexto novo de civilização: o lusotropical. Lisboa: Comissão Executiva das Comemorações do V Centenário da Morte do Infante D. Henrique, 1961.

Lepecki, Maria Lúcia. "Luís Bernardo Honwana: o menino mais seu cão". Literaturas africanas de língua portuguesa. Lisboa, Fundação Gulbenkian, 1987, p. 45-55.

Macagno, Lorenzo. Lusotropicalismo e nostalgia etnográfica: Jorge Dias entre Portugal e Moçambique. Afro-Ásia, n.28, p.97-124, 2002. Disponível em: https://portalseer.ufba.br/index.php/ afroasia/article/view/21045. Acesso em: 27 de mai. 2017.

Melo, Alfredo Cesar. Relendo Freyre contra Freyre: apropriações contra-hegemônicas do hibridismo no Atlântico Sul. Via Atlântica, São Paulo, v.1, n. 25, p. 83-101, Jul. 2014. Disponível em: $<$ http://www.revistas.usp.br/viaatlantica/article/view/69522>. Acesso em: 27 mai. 2017.

Mondlane, Eduardo. "Resistência - A procura de um movimento nacional". In: Sanches, Manuela (Org.). Malhas que os impérios tecem: textos anticoloniais, contextos pós-coloniais. Lisboa: Edições 70, 2011, p. 333-354. 